Journal DOI: www.doi.org/10.46654/AJBED

Article DOI: www.doi.org/10.46654/AJBED.1525

\title{
INTERPERSONAL TRUST AND EMPLOYEE JOB SATISFACTION OF PRIVATE SECURITY FIRMS IN RIVERS STATE, NIGERIA
}

\author{
OBULOR, Gospel Azubuike \& ALAGAH, Adekemi Drusilia \\ $1 \& 2$ Department of Management, \\ University of Port Harcourt, Nigeria. \\ gospelobulor@yahoo.com \\ alagahk@gmail.com
}

\begin{abstract}
Building trust among individuals especially employees is key to achieving stated objectives. In this sense, building interpersonal trust among employees could translate into several positives which may include satisfaction on the job. This study seeks to ascertain if employees are satisfied or enjoy their job especially when they interact with themselves based on trust. 126 security personnel from 15 private security firms in Rivers State were administered copies of the questionnaire accordingly. Only about 73\% representing 92 copies were retrieved successfully and used. Spearman's Rank Order Correlation Coefficient with the aid of Statistical Package for Social Sciences (SPSS) was used to conduct the analysis. The outcome revealed that enhancing interpersonal trust in terms of vertical trust and horizontal trust is essential in improving the level of satisfaction of employees. It was recommended that; Organizations should develop trust in their employee-employer relationships so as to enhance employee engagement and increase employee retention. Organizations should institutionalize trust in their dealings with employees in order to create a flexible working environment that boosts employee productivity. Organizations should encourage trusting work relationships amongst employees to improve communication and reduce employee absenteeism. Organizations should create a working environment that builds trust amongst employees if they must encourage employee advocacy and lower voluntary turnover. Organizational leadership should create amiable climate that builds team spirit, and contribute positive results towards reducing long-term human resource costs.
\end{abstract}

Keywords: Interpersonal Trust, Vertical Trust, Horizontal Trust, Employee Job Satisfaction, Cognitive Satisfaction, Affective Satisfaction, Leadership Climate, Security Firms. 


\section{Introduction}

Issues of safety and/or security are of top priority in the lives of people daily. This makes individuals, as well as the government, put in place safety and security measures in a bid to eradicate or curb criminal tendencies that threaten our existence. In whatever dimension it comes; security systems have been known to ward-off eventualities that have attempted to destroy our lives and property. These security systems namely; residential, commercial, computer, fire, personal safety, electric, and global security systems have been designed for the safety of lives and property. These issues cannot be downplayed if such an organization or entity wants to find itself on the global map. Typically, private security formations in Nigeria are approved and licensed to register and operate security outfits since this phenomenon appears to be of concern for all. This move has raised several concerns regarding the kind of employees that will adequately fit into their position expectations and sufficiently perform the required task. Again, the issue of what is commensurate in the forms of wages and salaries will make these individuals seem fulfilled performing their required tasks like their counterparts in other climes.Interestingly, these issues are essential because the organization may not want to stand the risk of spending so much to train their employees and losing them to a sister organization. This is because, an employee who leaves, for instance, may physically be replaced, but their experiences, knowledge, and skills may not be replaced by the new employees who take over from them i.e., this new employee may or may not be better skilled at the job. Hence, the replacement by an individual who may possess the right combination of skills, experiences, and knowledge does not come that easy. Therefore, getting employees who are satisfied performing their jobs is making the rounds in the field of human resources, industrial psychology, and organizational behaviour (Allam, 2017). Thus, employees who seem unhappy, disgruntled, displeased, or discontented with their employments may likely withhold efforts that may take such organization from achieving its objectives. On the other hand, if employees are satisfied with their tasks and responsibilities, they appear to be better committed and dedicated to both the job and the leadership of such an organization (Wan, 2013). In this vein, employees may not be compelled to perform their daily tasks as such disposition will come naturally (Altuntas \& Baykal, 2010). And, they will on their own bring all their skills, knowledge, and experience to fashion a way out of any problem that may arise (Allam, 2017; Altuntas \& Baykal, 2010). On a similar note, the desire for one's effort erupts naturally when satisfaction is feasible from carrying out the task.

Historical managerial data tend to reveal that the need to ascertain the behaviour of employees has been a serious concern for researchers for about seven decades today. They attempted to evaluate and re-evaluate employee behaviour using technological apparatus on employees who worked in a factory (Steinfield \& Fulk, 1990). In the wake of 2007, Latham and Budworth attempted to ascertain the level of satisfaction employees get when they carry out their tasks and responsibilities and how they interact with their superiors and network with other internal and external stakeholders. They discovered that employees tend to have a higher level of satisfaction on the job when they enjoy cordial relationship with these stakeholders as it tends to improve their performance. In the light of the above, organizations that intend to get the best out of their employees and ensure toretain those that are skillful, such an organization must create an enabling environment for such employees to showcase their skills, talent, and experiences. Thus, it is cheaper to retain these employees as compared to hiring more employees who will require training and supervision (Caralli, 2004). One of such ways to develop and prepare the employee is to create an atmosphere of trust and build the same through a clear leadership climate. 
As established by this disposition, organizations with a higher propensity of mutual trust between management and employees, and within the employees themselves may be able to attract and retain a more highly talented employee. In reality, an organization with highly qualified manpower is likely to perform better than organizations with less-qualified manpower. In this sense, the trust factor must be developed within the organization in a bid to achieve predetermined objectives. Within a social context, trust is typical of a scenario in which the parties involve willingly rely on the actions and inactions of one another to function. Trust represents a firm and strong belief in the ability and truth of an individual, group, and/or a process. This demonstrates that trust must take place between two or more entities, which represents interpersonal trust in this context. Interpersonal trust tends to show the trust in the relationship between employees, management, and employee and management.

Interpersonal trust tends to further show the trust levels in the vertical and/or horizontal relationships. First, vertical trust or trust between leaders and employees demonstrates ability, integrity, and benevolence and are the characteristics parties needed to play in a trust relationship. These characteristics are the basic ingredients that make up a model of perceived trustworthiness. More importantly, when these characteristics are displayed by management, employees tend to feel better and open towards management. In this sense, the interrelationship that exists between management and employees largely depends on the disposition of management. Employees who have perceived that management has been benevolent and has demonstrated the ability and integrity required to perform their role in an employee-management relationship have a high tendency of becoming loyal to their work and management. But when employees have perceived that management cannot be trusted with just anything, employees may likely become skeptical in their dealings with such management. Secondly, horizontal trust tends to deal with trust amongst co-workers. This demonstrates that the parties involved tends to have the same hierarchical status. Although, trust in this domain deals with the antecedents of the behaviour of employees in the relationship.

In the light of the above, several scholars have conducted studies on interpersonal trust and employee satisfaction respectively. However, none has been extensive and exhaustive enough to capture both concepts in a study especially considering the security sector of Rivers State, Nigeria. Based on this supposition, this study is designed to ascertain the influence of interpersonal trust inducing employee satisfaction specifically in security firms in Rivers State. Hence, this serves as a point of departure for the study.

Although, several research findings have proven that job dissatisfaction on the part of employees tends to have a major connection with employee turnover in several organizations and/or industries as well as other sectors. Hence, the security sector seems to have suffered a similar hit. Considering this, several factors have affected or caused employee dissatisfaction in the security sector. Some of these factors that have induced employee job dissatisfaction of private security firms may include but not limited to; poor and inconsistent pay, poor work/shift schedule, inadequate regulations, boredom and lack of basic work apparatus, poor treatment, lack of trust in the part of management, poor training amongst others.Other factors include lack of promotion, lack of recognition, poor working conditions, low levels of pay, large workload or overwork, limited career growth or progression, or advancement, underpaid salaries, poor management, unsupportive management, lack of meaningful worklife or lack of incentive for meaningful work-life and lack of work-life balance amongst 
others.All these factors have seemingly resulted in the loss of motivation, lack of infrastructure, poor performance, absenteeism, and high turnover rate.

In an attempt to reverse this ugly trend of events, this study is designed to introduce vertical and horizontal interpersonal trust as dimensions of interpersonal trust to bring about affective and cognitive satisfaction to reduce to the barest minimum, issues of employee dissatisfaction in private security firms in Rivers State.

\section{Theoretical Foundation}

A study such as this is expected to have a theoretical framework upon which the study could stand. In view of the above, related and relevant theories were reviewed and the affect control theory and two-factor theory were adopted to underpin this study. Thus, they serve as undergirded theories in this study. Affect Control Theory: The affect control theory was introduced in 1979 by an American psychologist; David Reuben JoromeHeise who was credited for originating the idea that affectual processes control interpersonal behavior. Heise proposes that affective control theory allows individuals to maintain affective meanings of events through their actions (or inactions) in interpreting such events (Heise, 1979). This means that individuals tend to measure semantically objects, concepts, and events that emanate as a result of their interaction with others. Thus, the affective control theory permits individuals in interaction with others to draw meaning and interpretation, form an impression, exhibit emotion, and take appropriate actions. In a trust-based interpersonal relationship, for instance, the actor (trustor and trustee) interprets and form an impression about the events in the relationship that the action of the trustee will not negatively affect, harm, or hinder the interest of the trustor (Briff\&Heise, 1992; Heise, 1979; 2006). Affective control theory holds that an actor in a relationship could evaluate an action or event of/by other actors in terms of their goodness or badness, activity in terms of their liveliness or torpidity, and potency in terms of their powerfulness or powerlessness. This further demonstrates that the connotation drawn from the actions of others in a trust-based relationship is centered on Evaluation, Potency, and Activity (EPA), of the fundamental issues based on the social life of the actors (in this case their identities, behaviours, settings, personal attributes, and emotions.

Two-Factor Theory: The two-factor theory is a model of employee motivation, propounded by an American psychologist; Frederick Irving Herzberg in 1959. Herzberg submits that employee or job satisfaction and employee or job dissatisfaction are generally influenced by separate factors, which function independently of each other (Herzberg et al., 1959). Herzberg's two-factor theory or the motivation-hygiene theory or Duel structure theory holds that individuals are seemingly not content with the satisfaction of lower-order needs at work, e.g. safe working environment and/or minimum salary levels. Rather, these individuals are seemingly gratified with higher-order needs at work, e.g. recognition, advancement, achievement, responsibility, and the nature of work itself (Herzberg et al., 1959). More specifically, the two-factor theory is guided by two basic principles; (1). Improve motivator factors to increase job satisfaction, (2). Improve hygiene factors to decrease job dissatisfaction. It is imperative to note that the motivator-factors may include; achievement, recognition, work itself, responsibility, personal growth, advancement, status, promotion, and stimulating work. While, hygiene-factors may include; co-worker interpersonal relationships, working conditions, base wage and salary, organizational policies and rules, quality of supervisor, job security, and work-life balance. 


\section{Conceptual Review}

Here, the idea is to create a detailed picture of interpersonal trust, vertical trust, horizontal trust, employee job satisfaction, affective satisfaction, cognitive satisfaction, and leadership climate. The intention is to emphasize an elaboration on the meaning of the concepts under review and show what other scholars think about them as well as their interrelationships.

\section{Concept of Interpersonal Trust}

An interpersonal trust permits an individual to willingly accept some form of vulnerability based on their expectation of others towards them. This represents the perception individuals hold towards others that their interests will not be hindered or harmed (Ellonen et al., 2008). Interpersonal trust also means a belief that a person is honest, sincere, and benevolent to another person. Sheik-Mohammed et al (2012) revealed that the basic elements of interpersonal trust are; horizontal trust and vertical trust. The former deals with trust that exists between employees. This kind of trust allows an employee to have the belief that their colleagues are not going to hinder or harm anything (tangible or intangible) that is of interest to them. This kind of trust exists amongst workers on the same level within an organization. While, the latter, deals with trust that exists between employees and their supervisors, foremen, leaders, and management of the organization. Interpersonal trust demonstrates the degree of confidence in an individual who is willing to act in favor of others or all involved (Allam, 2017). Zia and Khan (2014) in their work on organizational trust, cascaded interpersonal trust into two basic categories; trust in a person's competence and trust in a person's benevolence. The trust in a person's competence is a typical scenario of boarding an aircraft from one point to another without ascertaining the competence of the pilot. At this point, people just take it for granted that they will safely land at their destination without any disruptions. The second scenario deals with the gesture of magnanimity. This type of trust brings about confidence to the beneficiaries that the benefactor will act in a certain manner that will help them achieve their interest.

Oladipo et al. (2013), and Shahzad et al. (2010) explained that interpersonal trust can only come to light where the leadership style that exists in such an organization creates standard norms that induce trusting behaviours. This means that the prevailing culture that exists within the organization demonstrates trusting and trust-enhancing behaviours that could make the organization grow. Alzyoud (2018), Fabian et al. (2014), and Shahzad et al. (2010) stated that trust has demonstrated enough proof to induce employee engagement. Thus, the firm belief that may exist between employees for them to value their relationship, enjoy mutual respect, and higher levels of commitment which could make employees want to stay on their job and put in their best to make things work within the organization.

\section{Vertical Trust}

Vertical trust represents the trust that exists between the employee and the employer (Bakiev, 2013). Guinot et al. (2014), Lodisso (2020), and Allam (2017) explained that vertical trust could be viewed in the light of belief and confidence that may exist in an employee-employer relationship. It is imperative to note that vertical trust goes a long way to determine the outcome of several events in the organization. For instance, an employee who is having a hard time trusting their employer(s) may not want to commit to their job. In the same vein, an employer (organizational leadership) does not have trust in their employees, or employees who are not trustworthy is likely to run into trouble considering the need(s) of the organization concerning employee inputs. Vertical trust tends to engender organizational leadership to build knowledge and expertise that could be transferred to employees to enable 
them adequately deliver on their job (Yu \& Choi, 2014; Velez \& Strom, 2012). This means that the process of creating, developing, and transferring work-based knowledge by the organization would help organizational leadership to "entrust" essential duties to the employees, and have a firm belief as well as confidence in them (employees) that they would deliver on the job. Ellonen et al. (2008) explained that building vertical trust revolves around a balancing technique that would allow for and support the creation and transfer of knowledge within the organization. Additionally, Ellonen (2008) explained that the focus will no longer be directed towards individual or group efforts, but institutional trust which is, therefore, more likely to have a harmonizing effect on interpersonal trust.

\section{Horizontal Trust}

Horizontal trust is the belief that employee has within themselves that their interests are always going to be protected. Ellonen et al. (2008) explained that horizontal trust could potentially induce innovative work behavours on the part of employees. They explained that innovative work behavior (or innovative behavior) provides the employee with freedom to act; which tends to increase the desire of employees to act freely and creatively in favour of the organization. It is pertinent to note that employees in this sense tend to experiment and act by themselves. Innovation and/or innovative behavior has its inherent complexity and uncertainty, which is why the element of trust especially between employees is a key factor that could drive the creation, adoption, implementation, and improvement of innovation by employees (Ellonen et al., 2008; Lewicka, 2015). This is because trust induces individuals to takes risks without any fear of failure and undue consequence. An employee who trusts that his/her ideas will be appreciated will more likely cultivate novel ideas since they seemingly feel safe to try new things (Lewicka, 2015). Lewicka (2015) opined that building horizontal trust is an interactive process that allows employees to learn, unlearn, and re-learn new attitudes, aptitudes, skills, and so on to help the employee carry out their task optimally. Lewicka (2015), and Barkieer (2013) explained that horizontal trust is important because it allows the trustor to depend on the future actions of the trustee to achieve their object. What they seemingly found interesting is the fact that this issue is centered on only employees. Horizontal trust is categorized into; (1) deterrence-based trust, (2) knowledge-based trust (3) identification-based trust. Deterrence-based trust is the trust people have in others when they believe that (for these others) the cost of breaching this trust may outweigh the supposed benefits of being untrustworthy. While knowledge-based trust is that trust that deals with the ability to predict the behavioural outcome of the trustee based on prior or previous performance. Lastly, the identification-based trust holds that the highest level of trust could be achieved when there is an emotional connection between the parties involve (Lewicka, 2015). Horizontal trust is a good ingredient for team building. It allows each player to demonstrate benevolence, competence, and integrity; which are key factors in building a formidable team as it creates a conducive working-environment due to familiarity and good relationship that exist between employees. Finally, horizontal trust builds skills and abilities, emotional attachment between employees, and develops consistency in the behaviours of employees.

\section{Concept of Employee Job Satisfaction}

Employee or job satisfaction represents a measure of contentedness of employees about their jobs (Allisey et al., 2014; Maleknia et al., 2011; Nalla \& Cobbina, 2017; \& Simatwa, 2011). Locke (1976) opined that employee satisfaction represents a positive emotional state that comes as a result of one's job or experiences. These definitions of employee satisfaction could be cascaded using several variables, concepts, and measures to paint a graphic picture 
of employee satisfaction. In line with this, Herzberg's motivation-hygiene factors are collapsed and expanded to get a deeper meaning of employee satisfaction. For instance, Recognition (desirable arms and commendations, are immediate gratification), Good compensation offer (pay equity, fringe benefits, and bonuses), Autonomy (authority and responsibility) work-life balance (time management and stress management), Career Advancement (career awareness and skills development), Supportive Working Conditions (physical wellbeing and emotional wellbeing), Good Leadership Practices (team building, honesty, and integrity), Job Security (sense of assurance and sense of comfort), Personal Growth (Improving skills and developing strength and talents), Good Interpersonal, Relationship (deep connection, and close association), Clearly Defined Objectives (plans, and values), Feedback (proactiveness, and timeliness). These were collapsed according to the works of Judge and Watanabe (1994), Judge et al. (2002), Judge and Larsen (2007), and Judge and Kammeyer-Mueller (2008).

Judge et al. (2001), and Judge and Klinger (2007) explained that employee satisfaction increases organizational profits, helps employees to support the mission of the organization, and helps the organization to achieve hard work on the part of employees. Judge et al. (2001), and Halin and Judge (2003) explained that employee satisfaction could bring about good citizenship behavior and enhance the interpersonal relationship while eliminating deviant work-related behaviours such as absenteeism and presenteeism. Olorusola (2012), and Rajab (2014) revealed that employee satisfaction is a result of motivation and it enhances the personal characteristics of employees at several points in their organizational life. Employee satisfaction is considered a key factor that predicts the individual well-being in its entirety, as well as a predictor of employee intention to stay or leave an organization (Fard \& Karimi, 2015; Alyoud, 2018). Employee satisfaction is increasingly becoming an impartment factor in the everyday life of individuals. This is because organizations seemingly have significant effects on the individuals that are under this employ, and some of these effects reflect on how employees perceive their work as well as how they feel about their jobs. Hence, achieving employee satisfaction becomes extremely important to both the employee and the employer. Based on these submissions, it is important to note that many studies have suggested that both the employee and the employer are beneficiaries of employee satisfaction. On one hand, employee satisfaction lowers voluntary turnover, reduces employee absenteeism, increases employee retention, boosts employee productivity reduces long-term human resources costs and contributes positive resents towards achieving employee referrals. On the other hand, employee satisfaction enhances personal growth and development, improves interpersonal relationships, assures job career advancement, provides a platform for a good compensation offer, and includes employee recognition (Amir \& Amen, 2014; Alamadar et al., 2002; Jifendra \& Mini, 2013; Khan et al., 2012; \& Weiss, 20020. Hulin and Judge (2003) explained that employee satisfaction could be measured on the components of affective satisfaction, cognitive satisfaction, and behavioural satisfaction.

\section{Affective Satisfaction}

Within the context of employee job satisfaction, affective satisfaction represents the subjective feelings perceived by an employee while performing tasks and responsibilities assigned to such employees (Judge et al, 2017; Davies et al., 2017). This represents a positive emotional response to one's work as a whole. Affective satisfaction is mostly considered related and/or associated with overall or general satisfaction especially about how people like or dislike their work (Cantarelli et al., 2016; Davies et al., 2017). This implies that affective satisfaction tends to evaluate the expected, desired, and or promised level of quality or 
standard of work-related attainment by the organization (Spector, 1997). In specific turns, affective job satisfaction relates to job emotions or the emotional status of the employees with regards to their job, and the tasks and responsibilities that come with it. Collins et al. (2014) explained that affective satisfaction allows for the adaptive responses to changes and challenges in the work environment. Indeed, affective job satisfaction is a revolutionary factor that tends to address issues relating to ill-feeling that may arise in the workplace due to poorly managed emotional outcomes. Karin et al. (2014) explained that affective job satisfaction relates to employees feeling excited, related, happy, related, calm, and contented with their jobs. This means they are not easily irritated, tensed, stressed upset, fatigued, board, sail, and/or depressed about their job. Affective satisfaction is the compassionate feelings employees demonstrate towards their job(s) or task, and responsibilities. Again, Miao et al. (2017) explained that affective satisfaction addresses issues that are hard to handle for the organization. These emotions are many like insecurity, frustration, major dislikes, and feelings of disappointments. Lack of Affective satisfaction has been an issue that has affected all stakeholders - employees and employers alike. If the employees have positive feelings towards their job or feel passionate about it, they are likely to experience positive job outcome. The organization on other part is enjoying lower voluntary turnover, increased employee retention, reduced employee absenteeism, increased employee productivity, reduced long-term human resource cost, and general positive organizational outcomes (Laguna et al., 2017; Tabachnick \& Fidell, 2013)

Hulin and Judge (2003) examined the interconnection between affective disposition and subjective wellbeing. The study thus investigated the correlation between the tendency to have positive or negative thoughts and emotions and the perceived level of satisfaction about life in general. The outcome of this study holds that affective disposition could positively impact subjective wellbeing. That is, subjective wellbeing had a positive impact on employee satisfaction. This indicates that aside from the content and characteristics of the job itself, the affective disposition of employees is key to determining the level of satisfaction employees derive from their job. In this case, job satisfaction influences the overall satisfaction individuals get from their personal life especially if their job is befitting. This implies that an employee who is dissatisfied with their job but seems satisfied with their personal life may invariably perform better on their job. On the other hand, employees who are seemingly satisfied with their job, but are seemingly dissatisfied with their life may become poor performers on the job.

\section{Cognitive Satisfaction}

Cognition connotes a mental state, process, or action of understanding or acquiring knowledge through experience or intellectual function (Ardila, 2018). It thus cuts across many aspects of intellectual functions and processes such as attention, the formation of knowledge, memory, and working memory, measurement and evaluation, reasoning and problem-solving, and decision making, comprehension, and production of philosophical direction. Blomberg (2011), and Ardila (2018) explained that a cognitive process applies existing knowledge and generates new knowledge. It thus analyses different perspectives within different contexts, notably in education, computer science, psychology, and so on. These are other diverse ways in which the analysis of cognition is connected to the development of the human mind. Cognitive satisfaction connotes a mental process of fulfillment an employee gets from performing their job (Oliver, 1993). Cognitive satisfaction could manifest as a result of interesting and challenging work. Smith (2013) opined that challenging work demands can be a huge motivator for employees as it can keep them fully 
engaged on the job, and their attention and interest in their role. Experience has shown that more individuals attempt to overcome the difficulties in their job by taking up more challenging tasks. This means, having to overcome some level of difficult situations about their job is highly preferable to the boredom of an easy and unchallenging task, responsibility, and/or rote (Smith, 2013).

Smith (2013) further explained that this positive effect that comes with the challenging job(s) and task(s) could however lead to a frustrating situation to the point that job performance could be practically impossible if there is no adequate plan for resources, skills, and management support required to take the organization to another level. Specifically, Smith (2013) revealed that the challenges of a potholer job are likely to be intrinsic to the role, however, organizational leadership should ensure that employees are aware of how to access the needed training and required support especially when they are confronted with difficult tasks, responsibilities, and roles. This training and support could make the employee happy with their job and with themselves. Thus, happiness with task, role, and responsibilities are partially tied to whether the employees have been able to grow and develop. This always goes a long way to enhance the chances of the employee making positive and worthwhile contributions.

\section{Relationship between interpersonal trust and employee job satisfaction}

Kim et al. (2009) opined that trust and satisfaction are key and essential for a business relationship or other form of relationships to be a success. This shows that interpersonal trust and employee job satisfaction go hand-in-glove. For instance, employees who are satisfied with their job owing to recognition, good compensation offer, work-life balance, autonomy, career advancement, supportive working environment, good leadership practices, job security, personal growth, good interpersonal relationship(s), clearly defined organizational objectives, and well-structured feedback mechanism will most likely invest their trust both in management, and in their peers to get the best out of their work-life. In the same vein, Matzler and Renzl (2006) reported that trusting leadership and trusting employees are more likely to be successful, as they will have employees who are satisfied with their jobs, such employees would want to be committed to performing their tasks and responsibilities optimally, and invariably remain loyal to their work and management. On this note, organizations are required to develop, build, and sustain a trusting environment that will induce other factors of job satisfaction. This way, employees would naturally stay committed and loyal towards their job, management, and organization.

\section{Leadership climate moderating the relationship between interpersonal trust and employee job satisfaction}

Leadership competencies have been shown to induce trust and satisfaction at several levels. In most cases, employee's perception of job satisfaction is tied to the competencies of the leadership of the organization, and how they (leaders) deal with trust on an interpersonal basis. To buttress this point, Asencio (2016) conducted a study on leadership trust and job satisfaction among public sector employees. The outcome of the study holds that leadership (Weather transactional or transformational) enhances employee satisfaction, through employee trust in management and trust in peers. Thus, leadership plays a more significant role in the relationship between individualized considerations (trust) and employee satisfaction. Again, it was revealed that leadership that is aimed at transforming the lives of employees will significantly create a more positive impact in the lives of organizational members, especially employees. Ansencio (2016) based on the outcome of this study 
suggests that organizational leaders need to focus on developing considerable leadership competencies to build a more satisfied and productive employee.

\section{Empirical Review}

This section encompasses studies conducted by other researchers on several other concepts, variables, and constructs in conjunction with either interpersonal trust or employee satisfaction, or both. In view of this, Amir and Amen (2014) conducted a study on the impact of employee engagement on job satisfaction: Theoretical study. They attempted to determine the link that connects employee engagement and job satisfaction using descriptive statistics based on data collection and analysis of other previous studies, periodicals, reports, and books. Amir and Amen (2014) found that employees should be involved or actively participate in decision-making that affects their primary assignment in the organization as this would give them some level of autonomy and ensure their personal growth within the organization. Interestingly, Ishita (2016) examined the relationship between job satisfaction and job performance among employees. In this study, job or employee satisfaction is viewed through the lens of promotion, pay, supervision, contingent rewards, fringe benefits, coworkers, operational procedures, communication, and nature of work, while job performance is viewed through the lens of task performance and contextual performance. Ishita (2016) applied descriptive statistics and inferential statistics to analyze the demographic data of seventy-seven (77) full-time employees. It was found that job satisfaction and job performance are closely related in which co-workers, and supervision are the central factors that induced job satisfaction among employees. Thus, the job satisfaction elements mentioned above could be achieved if task performance and contextual performance are taken seriously.

Nwizia et al. (2017) investigated employee's job satisfaction in conjunction with organizational politics in the health sector. The cross-sectional research design was used to study two hundred and seventy-four (274) employees in this regard. The study applied Spearman's Rank Order Correlation Coefficient with the aid of a statistical package for social sciences (SPSS). The findings of the study revealed that there is a significant correlation between politics in an organization and employee's job satisfaction. It was recommended that organizational leadership should actively focus on positive political behaviours. Thus, management should be apolitical in the payment of bonuses and other fringe benefits as this would go a long way to trigger the satisfaction of employees in the organization. Hong et al. (2013) investigated factors that affect job satisfaction amongst employees. In this study, factors such as; gender, age, wages, and level of education are examined in line with job satisfaction. This means the level of satisfaction employees get from their jobs was analyzed based on their demographic factors. The sample size is thirty-five (35) employees, while the Non-parametric statistical tool such, as the Kruskal-Wallis test, frequency, and Wilcoxon signed-rank test were applied using the SPSS software. Here, the factors of job satisfaction such as; salary and pay, fairness and promotion, and work environment are classified as independent variables, while the level of satisfaction is classified as the dependent variable. Hong et al. (2013) reported that the study revealed pay and salary, fairness and promotion, and work environment significantly impact the level of satisfaction employees get on their job, except for fairness which does not show any significant relationship with the level of employee satisfaction.

Hassan et al. (2012) examined interpersonal trust and its role in organizations. They conducted an in-depth review of the concept of interpersonal trust, its antecedents, and consequences. The concept of interpersonal trust was reviewed alongside other variables, constructs, and concepts such as; employee empowerment, feedback from and to employees, 
and trust between supervisors and employees. Hassan et al. (2012) summarized that the concept of trust is an important phenomenon that is increasingly gaining more attention. According to this study, trust shows the nature and importance of having trusting business and interpersonal relations. Its relevance could be felt more when the employees trust their supervisors as trust is an effective tool to induce positive organizational outcomes. Hassan et al. (2012) concluded that trust-building practices between employees and employers can positively lead to higher organizational commitment and productivity. Judeh (2011) investigated interpersonal trust; while considering demographic characteristics of employees and management. The study aimed at uncovering interpersonal trust issues concerning marital status, experience, gender, and level of education. A sample of one hundred and ninety-six (196) employees was drawn from the population and one hundred and ninety-six (196) copies of the questionnaire were administered. The finding of the study revealed that there are no differences in interpersonal trust based on marital status, gender, or level of education. The outcome of this study holds that there are no significant differences due to age and experiences. Judeh (2011) holds that this outcome has added to literature in interpersonal trust issues.

Allan (2017) investigated interpersonal trust among university employees in Saudi Arabia. This study aims to explore the degree of interpersonal trust among university employees in terms of their biographical characteristics such as nationality, gender, qualification, and experience. An interpersonal trust scale was developed in four dimensions namely; openness, communication, managerial competence, and professional support, surveyed on one hundred and twenty-five (125) randomly selected employees. Both descriptive and inferential statistics were applied in the analysis. The outcome of this investigation explained that; communication ranked the least by both female and male Saudi and non-Saudi employees, female employees shows a higher level of professionalism and support. In all aspects of interpersonal trust (as used in this study) trust ranked highest amongst employees with higher education. It was therefore recommended that interpersonal trust should be enhanced to get the best out of employees. Feng et al. (2003) examined interpersonal trust and empathy online: a fragile relationship. This study was conducted with a focus on the effect of empathy and response type on an online interpersonal relationship. The experimental research design was employed to survey twelve respondents. The outcome of the study revealed that both empathic accuracy and response type have a significant influence on online interpersonal trust. Although, the interaction between empathic accuracy and response type is the dominant factor in interpersonal trust. This result implies an interesting relationship between general trust attitude and online interpersonal trust.

Matzlere and Renzl (2006) investigated the correlation between interpersonal trust, employee satisfaction, and employee loyalty. The purpose of this study is to examine the important drivers of employee satisfaction. Interpersonal trust was dimensionalized using trust in management (vertical trust), and trust in peers (horizontal trust). The study revealed that trust in management and trust in peers positively and strongly influence employee satisfaction which results to employee loyalty. This means that an organization with trusting leadership and employees invariably have employees that are satisfied, committed to their job, and loyal to management. The study explored structural equation modeling with Partial Least Squares (PLS) in conducting the analysis. Salleh et al. (2015) explored the relationship between interpersonal trust and job satisfaction on organizational commitment. The study was conducted using eighty (80) respondents, and job satisfaction and interpersonal trust as predictors of organizational commitment. The study adopted a quantitative correlation 
research design, Likert scale questionnaire, simple random sampling, and descriptive statistics. The findings revealed that organizational trust and job satisfaction were found to have a medium to strong correlation with organizational commitment. This shows that job satisfaction and interpersonal trust are significantly and positively related to organizational commitment. This outcome indicates the firm which was used as the case study needs to focus on enhancing job satisfaction and trust among employees to stimulate, sustain, and improve organizational commitment.

Guint et al. (2014) examined interpersonal trust, stress, and satisfaction at work. The study adopted structural equation modeling to analyze the opinions of six thousand, four hundred and seven $(6,407)$ employees. The study revealed that interpersonal trust has a positive effect on job satisfaction, and job stresses partially moderates this correlation. Again, interpersonal trust is negatively related to job stress which ultimately results in a negative effect on job satisfaction. This study prompted the conclusion that cultivating a climate of trust may provide organizations with strategies to improve levels of mental wellbeing and satisfaction among employees. Guinot et al. (2014) explained that trust implies low-risk perception which is likely to reduce job stress which in turn increases job satisfaction. Bariman and Khorshidi (2018) examined the relationship between organizational trust and job satisfaction. The study applied descriptive statistics. The statistical population consists of all employees of Agricultural Bank Branches. The sample size is one hundred and five (105) respondents which were determined using the Cochran formula. These 105 participants were selected using strategies sampling based on their gender. The result of this study revealed that there is a significant and positive relationship between organizational trust and employee satisfaction. This study viewed organizational trust through the lens of horizontal trust, vertical trust, and institutional trust. Conclusively, the study submits that horizontal trust, vertical trust, and institutional trust predict the level of job satisfaction for employees.

\section{Research Hypotheses}

From the above research reviews, the following null hypotheses were formulated.

Ho 1 There is no significant relationship between vertical trust and affective satisfaction of private security firms in Rivers State.

$\mathbf{H o}_{2}$ There is no significant relationship between vertical trust and cognitive satisfaction of private security firms in Rivers State.

$\mathbf{H o}_{3}$ There is no significant relationship between horizontal trust and affective satisfaction of private security firms in Rivers State.

$\mathrm{Ho}_{4}$ There is no significant relationship between Horizontal trust and cognitive satisfaction of private security firms in Rivers State.

Ho5 Leadership climate does not significantly moderate the relationship between interpersonal trust and employee job satisfaction of private security firms in Rivers State.

\section{Methodology}

This study adopts the quasi-experimental research design, and the cross-sectional research design respectively. The total population comprised of all employee of the private security 
firms in Rivers State. Record from the human resources desk of the various firms showed a total of 126 employees from fifteen (15) selected private security firms which make up our accessible population. The census study method was used to determine the sample size. With the aid of this research tool, the entire population size was adopted as the sample size. Accordingly, there may be no need for sampling. The instrument was proportionally distributed with effect to the number of employees of the various security firms. This means $126(100 \%)$ copies of the questionnaire were administered. Only $95(75 \%)$ copies of the questionnaire were retrieved, meaning $3(2 \%)$ were either wrongly filled or incomplete and thus are invalid. Lastly, only $92(73 \%)$ of the mobilized questionnaire were considered valid and admissible and therefore utilized.

\section{Data Analysis}

In this section, data results for the analyses and tests for the bivariate hypotheses are presented. The section examines the relationship the dimensions of the predictor variable (interpersonal trust) and the measures of the criterion variable (employee satisfaction) which constitutes the objective. Four null bivariate correlations are tested in this section using Spearman's Rank Order Correlation Coefficient with the aid of Statistical package for social science (SPSS version 21.0) after the confirmation by test for normality. The decision rule is to accept the null hypotheses where $p>0.05$ significant level and reject the null hypotheses where $p<0.05$ significant level.

\section{$H_{O 1:}$ Table 1. Vertical Trust and Affective Satisfaction}

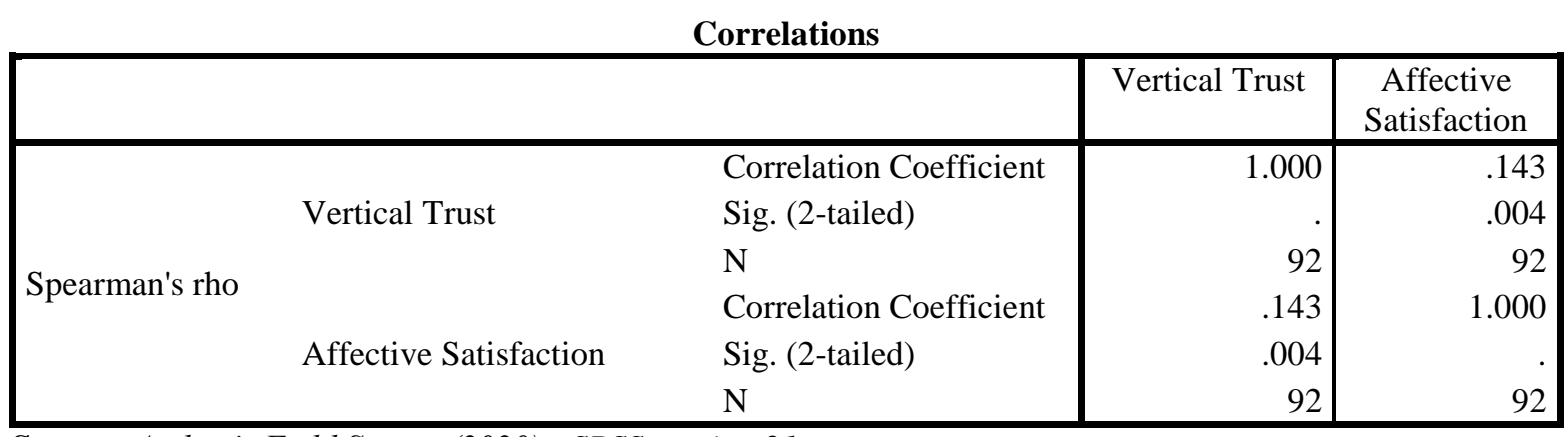

Source: Author's Field Survey (2020) - SPSS version 21 output extracts

There is no significant relationship between vertical trust and affective satisfaction of private security firms in Rivers State. The result of the analysis in Table 1 demonstrates a significant level $p<0.05(0.004<0.05)$, rho $=0.143$ linking both variables.

\section{$\mathbf{H}_{\text {O2: }}$ Table 2. Vertical Trust and Cognitive Satisfaction}

Correlations

\begin{tabular}{|lll|r|r|}
\hline & & Vertical Trust & \multicolumn{1}{c|}{$\begin{array}{c}\text { Cognitive } \\
\text { Satisfaction }\end{array}$} \\
\hline & \multirow{2}{*}{ Vertical Trust } & Correlation Coefficient & 1.000 & .155 \\
Spearman's rho & & Sig. (2-tailed) &. & .006 \\
& & $\mathrm{~N}$ & 92 & 92 \\
& \multirow{2}{*}{ Cognitive Satisfaction } & Correlation Coefficient & .155 & 1.000 \\
& & Sig. (2-tailed) & .006 &. \\
& & $\mathrm{~N}$ & 92 & 92 \\
\hline
\end{tabular}

Source: Author's Field Survey (2020) - SPSS version 21 output extracts 
There is no significant relationship between vertical trust and cognitive satisfaction of private security firms in Rivers State. The result of the analysis in Table 2 demonstrates a significant level $p<0.05(0.006<0.05)$, rho $=0.155$ linking both variables.

\section{$\mathbf{H}_{\mathrm{O3}}$ : Table 3.Horizontal Trust and Affective Satisfaction}

\begin{tabular}{|lll|r|r|}
\hline & & \multicolumn{1}{c|}{ Correlations } \\
& & $\begin{array}{c}\text { Horizontal } \\
\text { Trust }\end{array}$ & $\begin{array}{c}\text { Affective } \\
\text { Satisfaction }\end{array}$ \\
\hline & \multirow{3}{*}{ Horizontal Trust } & Correlation Coefficient & 1.000 & .223 \\
Spearman's rho & & Sig. (2-tailed) &. & .032 \\
& & $\mathrm{~N}$ & 92 & 92 \\
& Affective Satisfaction & Correlation Coefficient & .223 & 1.000 \\
& & Sig. (2-tailed) & .032 &. \\
& & $\mathrm{~N}$ & 92 & 92 \\
\hline
\end{tabular}

Source: Author's Field Survey (2020) - SPSS version 21 output extracts

There is no significant relationship between horizontal trust and affective satisfaction of private security firms in Rivers State. The result of the analysis in Table 3 demonstrates a significant level $p<0.05(0.032<0.05)$, rho $=0.223$ linking both variables.

\section{$\mathrm{H}_{\mathrm{O4}}$ : Table 4. Horizontal Trust and Cognitive Satisfaction}

\section{Correlations}

\begin{tabular}{|c|c|c|c|c|}
\hline & & & $\begin{array}{l}\text { Horizontal } \\
\text { Trust }\end{array}$ & $\begin{array}{c}\text { Cognitive } \\
\text { Satisfaction }\end{array}$ \\
\hline \multirow{6}{*}{ Spearman's rho } & \multirow{3}{*}{ Horizontal Trust } & Correlation Coefficient & 1.000 & .250 \\
\hline & & Sig. (2-tailed) & . & .008 \\
\hline & & $\mathrm{N}$ & 92 & 92 \\
\hline & \multirow{3}{*}{ Cognitive Satisfaction } & Correlation Coefficient & .250 & 1.000 \\
\hline & & Sig. (2-tailed) & .008 & . \\
\hline & & $\mathrm{N}$ & 92 & 92 \\
\hline
\end{tabular}

Source: Author's Field Survey (2020) - SPSS version 21 output extracts. 
There is no significant relationship between horizontal trust and cognitive satisfaction of private security firms in Rivers State. The result of the analysis in Table 4 demonstrates a significant level $p>0.05(0.008>0.05)$, rho $=0.250$ linking both variables.

\section{$H_{O 5:}$ Table 5. Leadership climate and the relationship between interpersonal trust and employee satisfaction}

\begin{tabular}{|c|c|c|c|c|}
\hline \multicolumn{5}{|c|}{ Correlations } \\
\hline \multicolumn{3}{|c|}{ Control Variables } & $\begin{array}{c}\text { Interpersonal } \\
\text { Trust }\end{array}$ & $\begin{array}{c}\text { Employee } \\
\text { Satisfaction }\end{array}$ \\
\hline \multirow{7}{*}{-none- ${ }^{a}$} & \multirow{3}{*}{ Interpersonal Trust } & Correlation & 1.000 & .214 \\
\hline & & $\begin{array}{l}\text { Significance (2- } \\
\text { tailed) }\end{array}$ & & .006 \\
\hline & & Df & 0 & 90 \\
\hline & \multirow{4}{*}{$\begin{array}{l}\text { Employee } \\
\text { Satisfaction }\end{array}$} & Correlation & .214 & 1.000 \\
\hline & & Significance (2- & .006 & \\
\hline & & tailed) & & \\
\hline & & Df & 90 & 0 \\
\hline \multirow{7}{*}{$\begin{array}{l}\text { Leadership } \\
\text { Climate }\end{array}$} & \multirow{3}{*}{ Interpersonal Trust } & Correlation & 1.000 & .260 \\
\hline & & $\begin{array}{l}\text { Significance (2- } \\
\text { tailed) }\end{array}$ & & .002 \\
\hline & & Df & 0 & 89 \\
\hline & \multirow{4}{*}{$\begin{array}{l}\text { Employee } \\
\text { Satisfaction }\end{array}$} & Correlation & .260 & 1.000 \\
\hline & & Significance (2- & .002 & . \\
\hline & & tailed) & & \\
\hline & & Df & 89 & 0 \\
\hline
\end{tabular}

a. Cells contain zero-order (Pearson) Correlations.

Source: Author's Field Survey (2020) - SPSS version 21 output extracts

Leadership Climate does not significantly moderate the relationship between interpersonal trust and employee satisfaction of private security firms in Rivers State. The study observed from the probability of 0.002 that the moderating variable significantly moderates the linking of both variables. All null hypotheses were rejected and the alternate hypotheses were accepted.

\section{Discussion of Findings}

The bivariate analysis demonstrates a significant correlation between the predictor and criterion variables. Hence, leadership climate has been observed to influence the correlation between the predictor and criterion variables. This is discussed thus:

\section{Vertical trust and affective satisfaction}

The report revealed a coefficient $\mathrm{p}$-value of 0.004 which is less than $0.05(\mathrm{p}=0.004<0.05)$. This implies that vertical trust has a significant correlation with affective satisfaction. The result of the Correlation Coefficient (r) is 0.143 . $\left(r^{2}\right)$ shows a value of 0.02 which implies a $2 \%$ total variation in affective satisfaction. These findings align with the studies of Bakiev (2013) which hold that interpersonal trust influences employee commitment and increases performance. 


\section{Vertical trust and cognitive satisfaction}

The report revealed a coefficient $p$-value of 0.006 which is less than 0.05 level of significance $(\mathrm{p}=0.006<0.05)$. Implies a correlation between vertical trust and cognitive satisfaction at 0.155 . $\left(\mathrm{r}^{2}\right)$ was 0.024 . This demonstrates a $2.4 \%$ total variation in cognitive satisfaction. These findings align with the studies of Guinot et al. (2014) which explained that interpersonal trust has a positive effect on employee satisfaction.

\section{Horizontal trust and affective satisfaction}

The report revealed a coefficient $\mathrm{p}$-value of 0.032 which is less than 0.05 significance level $(\mathrm{p}=0.032<0.05)$. This implies a correlation between horizontal trust and affective satisfaction. The result of the relationship value ( $r$ ) was 0.223 . The coefficient of determination $\left(\mathrm{r}^{2}\right)$ was 0.049 . This indicates that $4.9 \%$ of the total variation in affective satisfaction. These findings align with the studies of Meral at al. (2016) which revealed that trust in the workplace has a positive significant relationship with the employee satisfaction of employees in the organization.

\section{Horizontal trust and cognitive satisfaction}

The report revealed a coefficient p-value of 0.008 was less in comparison to the level of significance of 0.05 . The relationship value (r) demonstrates a value of 0.250 . This demonstrates a positive correlation between horizontal trust and cognitive satisfaction. This indicates a $6 \%$ total variation in cognitive satisfaction. These findings align with the studies of Matzler and Renzl (2006) which hold that interpersonal trust does significantly relate to satisfaction.

\section{Leadership climate, interpersonal trust, and employee satisfaction}

The multivariate analysis of the moderating influence of leadership climate on the relationship between interpersonal trust and employee satisfaction revealed a significant moderating influence of leadership climate. The report revealed a coefficient p-value of 0.002 was less than the level of significance (0.05). The positive relationship value of 0.260 demonstrates that an increase in the intensity of leadership climate is likely to increase the link between interpersonal trust and employee satisfaction by up to $26 \%$. These findings align with the studies of Alamdar (2012) that interpersonal trust enhances employee satisfaction under sound leadership climate.

\section{Conclusion}

Employees as humans are positively or negatively affected based on their emotions. Sometimes, they even have mixed feelings about the events or happenings around them. Although one can get the best out of them especially when they feel happy with themselves and with what they do. Like the saying, a happy worker is a productive worker. In other words, a happy employee tends to do more. That is, such employee will be more productive as compared to one who is unhappy. In this sense, one of the best ways to induce such mood is to introduce trusting habits especially among members of the organization. Thus, enhancing interpersonal trust in terms of vertical trust and horizontal trust is essential in improving the level of satisfaction of employees. This is because the inability to ensure interpersonal trust could lead to huge dissatisfaction. 


\section{Recommendations}

Guided by the aims and objectives, research questions, hypotheses, and data collection and analysis, the following recommendations are made to steer the operational activities of firms in the security sector:

- Organizations should develop trust in their employee-employer relationships so as to enhance employee engagement and increase employee retention.

- Organizations should institutionalize trust in their dealings with employees in order to create a flexible working environment that boosts employee productivity.

- Organizations should encourage trusting work relationships amongst employees to improve communication and reduce employee absenteeism.

- Organizations should create a working environment that builds trust amongst employees if they must encourage employee advocacy and lower voluntary turnover.

- Organizational leadership should create amiable climate that builds team spirit, and contribute positive results towards reducing long-term human resource costs. 


\section{References}

Alamdar, H., K., Muhammad M., N., Muhammad A., \&Wasim H., (2012). Impact of job satisfaction on employee performance: An empirical study of autonomous Medical Institutions of Pakistan. African Journal of Business Management 6(7), 2697-2705

Allam, Z. (2017). Interpersonal trust among university employees: An empirical investigation. International Journal of Academic Research in Business and Social Sciences, 7(4), 437-449. https://doi.org/10.6007/IJARBSS/V7-i4/2820.

Allisey, A. F., Noblet, A. J., Lamontagne, A. D., \&Houdmont, J. (2014). Testing a model of officer intentions to quit: The mediating effects of job stress and employee job satisfaction. Criminal Justice and Behaviour, 41(6), 751-771.

Altuntas, S. \& Baykal, U. (2010). Relationship between nurses' organizational trust levels and their organizational citizenship behaviours. Journal of Nursing Scholars, 42(2), 186194.

Alzyoud, A.A.Y. (2018). Job satisfaction and work engagementmoderated by trust. International Journal of Economics, Commerce and Management, 6(11), 125-139.

Amir, A., E., \& Amen I., (2014). The Impact of Employee Empowerment on Job Satisfaction Theoretical Study. American Journal of Research Communication. 2(1), 13-26

Ardila, A. (2018). Historical development of human cognition. A cultural-historical neuropsychological perspective. Springer.

Asencio, H. D. (2016). Leadership, trust, and job satisfaction in the publ;ic sector: A study of U.S. Federal employees. International Review of Public Administration, 21(3), 250267. https://doi.org/10.1080/12294659.2016.1237342.

Bakiev, E. (2013). The influence of interpersonal trust and organizational commitment on perceived organizational performance. Journal of Applied Economics and Business Research, 3(3), 166-180.

Blomberg, O. (2011). Concepts of cognition for cognitive engineering. International Journal of Aviation Psychology, 21(1), 85-104. https://doi.org/1080/10508414.2011.537561

Cantarelli, P., Belardinelli, P., \& Belle, N. (2016). A meta-analysis of job satisfaction correlates in the public administration literature. Rev. Public Pers. Adm. 36, 115-144. https://doi.org/10.1177/0734371X15578534

Caralli, R. A. (2004). Managing for enterprise security. Carnegie Mellon University.

Collins, B. J., Burrus, C. J., \& Meyer, R. D. (2014). Gender differences in the impact of leadership styles on subordinate embeddedness and job satisfaction. Leadersh. Q. 25, 660-671. https://doi.org/10.1016/j.leaqua.2014.02.003

Davies, E. M., Van der Heijden, B. I., \& Flynn, M. (2017). Job satisfaction, retirement attitude and intended retirement age: A conditional process analysis across workers' level of household income. Front. Psychol. 8:891. https://doi.org/10.3389/fpsyg.2017.00891 
Dunn, T.J., Baguley, T., \&Brunsden, V. (2014). From alpha to omega: A practical solution to the pervasive problem of internal consistency estimation. British Journal of Psychology. 105 (3), 399-412. https://doi.org/10.1111/bjop.12046

Ellonen, R., Blomqvist, K. \&Puumalainen, K. (2008). The role of trust in organisational innovativeness. European Journal of Innovation Management, 11(2), 160-181. https://doi.org/10.1108/14601060810869848

Fabian, O.U., Ike, E. O., \& Alma, R. S. (2014). Between organizational trust with employee engagement: The role of psychological empowerment. Personnel Review, 43(3), 377400 .

Fard, P.G. \& Karimi, F. (2015). The relationship between organizational trust and organizational silence with job satisfaction and organizational commitment of the employee of university. International Education Studies8(11), 219-227.

Feng, J., Preece, J. \& Lazar, J. (2003). Interpersonal trust and empathy online: A fragile relationship. Behaviour and information technology 23(2), 718-719. https://doi.org/10.1145/765891.765949.

Guinot, J., Chiva, R. \& Roca-Puig, V. (2014). Interpersonal trust, stress, and satisfaction at work: An empirical study, Personnel Review, 43(1), 96 - 115. https://doi.org/10.1108/PR-02-2012-0013

Heise, D. (1979). Understanding events: Affect and the construction of social actions. Cambridge University Press.

Heise, D. (2006). Sentiment formation in social interaction, in McClelland, Kent; Fararo, Thomas (eds), Purpose, Meaning, and Actions: Control Systems Theories in Sociology, 189-211.

Herzberg, F., Mausner, B. \&Syderman, B. B. (1959). The motivation to work ( $2^{\text {nd }}$ eds.). John Wiley.

Hassan, M., Toylan, N. V., Semercioz, F. \&Aksel, I. (2012). Interpersonal trust and its role in organizations. International Business Research, 5(8), 33-39 https://doi.org/10.5539/ib.v5n8p33.

Hong, L. C., Hamid, N. I., N. \&Salleh, N. M. (2013). A study on the factors affecting job satisfaction amongst employees of a factory in Seremban, Malaysia. Business Management Dynamics, 3(1), 26-40.

Hulin, C.L., \& Judge, T.A. (2003). Job attitudes. In W. C. Borman, D. R. ligen, \& R. J. Klimoski (eds.), Handbook of Psychology: Industrial and Organisational Psychology, Wiley.

Ishita, P. (2016). The impact of job satisfaction; while performing responsibilities. International Research Journal of Engineering and Technology, 3(7), 1859-1866.

Jifendra, K. S. and Mini, J. (2013). A study of employee's job satisfaction and its impact on their performance. Journal of India research, 1(4) 1-7. 
Judeh, M. (2011). Interpersonal trust and its relationship to demographic factors: An empirical study. European Journal of Scientific Research, 55(1), 154-163.

Judge, T. A., \& Watanabe, S. (1994). Individual differences in the nature of the relationship be-tween job and life satisfaction. Journal of Occupational and Organisational Psychology, 67,101-107.

Judge, T.A., \&. Heller, D. Mount, M.K. (2002). Five-factor model of personality and job satisfaction: A meta-analysis. Journal of Applied Psychology, 87(3), 530-541. https://doi.org/10.1037/0021-9010.87.3.530.

Judge, T. A., \& Klinger, R. (2007) Job satisfaction: Subjective well-being at work. In M. Eid, $\& R$. Larsen (Eds.), The science of subjective well-being. Guilford Publications.

Judge, T.A., \& Larsen, R. J. (2001). Dispositional affect and job satisfaction: A review and theoretical extension. Organisational Behavior and Human Decision Processes, 86(1), 67-98.

Judge, T.A., \&Kammeyer-Mueller, J.D. (2008). Affect, satisfaction, and performance. In N. M. Ashkanasy\& C. L. Cooper (Eds.), Research companion to emotion in organisations. Thousand Oaks, CA: Sage Publications, Inc.

Judge, T.A., Thoresen, C.J.; Bono, J.E., \& Patton, G.K. (2001). The job satisfaction-job performance relationship: A qualitative and quantitative review. Psychological Bulletin. 127(3), 376-407. https://doi.org/10.1037/0033-2909.127.3.376.

Judge, T. A., Weiss, H. M., Kammeyer-Mueller, J. D., \&Hulin, C. L. (2017). Job attitudes, job satisfaction, and job affect: A century of continuity and of change. J. Appl. Psychol. 102, 356-374. https://doi.org/10.1037/apl0000181

Karin, A., J., Lawter, L., Brockerhoff, M., \&Rutigliano, J. P. (2014). Cultural impact of human resource practices on job satisfaction: A global study across 48 countries. Cross Cultural Management, 21, 55-77. 10.1108/CCM-05-2012-0044

Khan, H.A., Nawaz, M.M., Aleem, M. \&Hamed, W. (2012). Impact of job satisfaction on employee performance: An empirical study of autonomous medical institutions of Pakistan. African Journal of Business Management, 6(7), 2697-2705

Kim, D. J., Ferrin, D. L. \& Rad, R. (2009). Trust and satisfaction, two stepping stones for successful 2-commerce relationships: A longitudinal exploration. Information systems research, 20(2), 237-257 https://doi.org/10.1287/isre.1080.0188.

Khorshid, S., \& Yazdani, H. (2012). The studying of relationships among trust, reciprocity, and organizational identification with considering the moderated effect of organizational commitment. Transformation Management Journal, 4(7), 62-90.

Laguna, M., Mielniczuk, E., Razmus, W., Moriano, J. A., \&Gorgievski, M. J. (2017). Crossculture and gender invariance of the Warr (1990) job-related well-being measure. $J$. Occup. Organ. Psychol. 90, 117-125. https://doi.org/10.1111/joop.12166 
Latham, G. P., \&Budworth, M.-H. (2007). The study of work motivation in the $20^{\text {th }}$ Century. In L. L. Koppes (Ed.), Historical perspectives in industrial and organizational psychology. Lawrence Erlbaum Associates Publishers.

Lewicka, D. (2015). Interpersonal trust at work and organizational and professional commitment interdependency model. Journal of Positive Management, 6(3), 83-100 httpo://dx.doi.org//10.12775/JPM.2015.017.

Locke, E. A. (1976). The nature and causes of job satisfaction. In M. D. Dunnette (Ed.), Hand- book of industrial and organisational psychology. Rand McNally.

Lodisso, S.L. (2020). The effects of interpersonal relationship on employee' jobsatisfaction: The case of education department, Hawassa CityAdministration. IOSR Journal of Business and Management, 21(3), 21-27.

Matzler, K. \&Renzl, B. (2006). The relationship between interpersonal trust, employee satisfaction, and employee loyalty. Total Quality Management and Business Excellence, 17(10), 1261-1271. https://doi.org/10.1080/14783360600753653.

Maleknia, H. R., Mehrabi, M., Hemati-nejad, M. A., \&Ramezan-nejad, R. (2011). The study of employee job satisfaction and organizational commitment among the employee of physical education general offices of Lorestan, Guilan, and Qom provinces. Quarterly Journal of sport Bioscience Researches, 1(3), 42-52.

Meral, Y., Yaşlığlu, M. \& Semerciöz, F. (2016). Effects of trust on job satisfaction and mediatory role of new identification between trust and job satisfaction in mergers. International Journal of Managerial Studies and Research, 4(5), 54-67

Miao, C., Humphrey, R. H., \& Qian, S. (2017). A meta-analysis of emotional intelligence effects on job satisfaction mediated by job resources, and a test of moderators. Pers. Individ. Dif. 116, 281-288. https://doi.org/10.1016/j.paid.2017.04.031

Nalla, M.K. \&Cobbina, J.E. (2017). Environmental factors and job satisfaction: The case of private guards. Security Journal, 30(1), 215-226.

Nwizia T., J., Ojiabo, U., \&Alagah A., D., (2017). Organisational politics and employee's job satisfaction in the health sector of Rivers State. International Journal of Advanced Academic Research | Social \& Management Sciences, 3(7), 88-106.

Oladipo, K. S., Jeffrey, L. D., Jamilah, O., Abu, D., \& Adekanye T. B. (2013). Investigation into the relationship between leadership styles and employee job satisfaction among employees in small and enterprises in Nigeria. International Journal of Business and Management,8(13), 34-41.

Oliver, R. L. (1993). Cognitive, affective, and attribute bases of the satisfaction response. $J$. Consum. Res. 20, 418-430. https://doi.org/10.1086/209358

Salleh, S.M., Zahari, A.S.M., Ahmad, F.H.M., Aziz, N.U.A. \& Majid, M.A. (2015). Exploring the relationship between interpersonal trust and job satisfaction on organizational commitment. Journal of Basic and Applied Scientific Research, 5(1)8590. 
Shahzad, K., Rehman, K. \& Abbas, M. (2010). HR practices and leadership styles as predictors of employee Attitude and Behaviour. European Journal of Social Sciences, 2(14), 67-100.

Simatwa, E.M.W. (2011). Employee job satisfaction and dissatisfaction among Teachers in Kenya. Kenya Journal of Education Planning Economics and Management, 3(3), $114-123$

Smith, M. (2013). Does challenging work really motivate staff? Fleximize fleximize.com/articles/001719/challenging-work-is-gren-for-staff-motivation.

Spector, P. E. (1997). Job Satisfaction: Application, Assessment, Causes, and Consequences. Thousand Oaks, CA: SAGE.

Steinfield, C.W. \&Fulk, J. (1990). The theory imperative, in organisations and communications technology, J. Fulk and C. W. Steinfield (eds.), Newbury Park, CA: Sage Publications.

Tabachnick, B. G., \&Fidell, L. S. (2013). Using Multivariate Statistics (6 ${ }^{\text {th }}$ eds). Northridge, CA: California State University.

Velez, P., \&Strom, T. (2012). Effects of organizational trust. Organisation Development Journal, 30(2), 39-50.

Weiss, H.M. (2002). Deconstructing job satisfaction: Separating evaluation, beliefs and affective experiences. Human Resource Management Review, 12(2), 173-194.

Yu, Y., \& Choi, Y. (2014). Corporate social responsibility and firm performance through the mediating effect of organizational trust in Chinese firms. Chinese Management Studies, 8(4), 592-577

Zia, Y. A., \& Khan, M. Z. (2014). Organizational trust: A cultural perspective. Journal of Humanities \& Social Sciences, 22(2), 12 7-134. 